\title{
Vertically-Suspended Environmental Enrichment Improves Growth of Landlocked Fall Chinook Salmon during Initial Hatchery Rearing
}

\author{
Nathan Huysman, Jill M. Voorhees, Eric Krebs, Michael E. Barnes \\ South Dakota Game, Fish and Parks, McNenny State Fish Hatchery, Spearfish, USA \\ Email: mike.barnes@state.sd.us
}

How to cite this paper: Huysman, N., Voorhees, J.M., Krebs, E. and Barnes, M.E. (2020) Vertically-Suspended Environmental Enrichment Improves Growth of Landlocked Fall Chinook Salmon during Initial Hatchery Rearing. Open Journal of Applied Sciences, 10, 725-731.

https://doi.org/10.4236/ojapps.2020.1011051

Received: August 27, 2020

Accepted: November 21, 2020

Published: November 24, 2020

Copyright $\odot 2020$ by author(s) and Scientific Research Publishing Inc. This work is licensed under the Creative Commons Attribution International License (CC BY 4.0).

http://creativecommons.org/licenses/by/4.0/

\section{(c) (i) Open Access}

\begin{abstract}
Environmental enrichment has been shown to improve juvenile salmonid growth during hatchery rearing. This study examined the effects of vertically-suspended environmental enrichment starting seven days after feed training and continuing for the next 32 days of landlocked fall Chinook salmon (Oncorhynchus tshawytscha) rearing. At the end of this experiment, final tank weights, gain, percent gain, and feed conversion ratio were all significantly improved in the tanks of salmon with environmental enrichment compared to barren tanks, with a nearly $25 \%$ improvement in feed conversion ratio. Individual salmon in tanks with environmental enrichment were significantly longer and weighed significantly more than salmon from tanks without enrichment. Specific growth rate was also significantly improved with the use of enrichment. The use of vertically-suspended environmental enrichment to improve growth and rearing efficiency is recommended during the initial rearing of landlocked fall Chinook salmon.
\end{abstract}

\section{Keywords}

Oncorhynchus tshawytscha, Environmental Enrichment, Structure, Initial Feeding

\section{Introduction}

Environmental enrichment is the modification of a typically barren hatchery rearing unit to add complexity or imitate natural environments. Physical structure has been added to fish rearing tanks as a form of environmental enrichment 
[1]-[7]. However, materials located at the bottom of the tank to mimic natural habitats have negative consequences for the hydraulic self-cleaning of circular tanks, leading to decreased water quality, increased labor requirements, and increased disease potential [8]-[13].

In order to add enrichment, but still maintain circular tank hydraulic self-cleaning, vertically-suspended environmental enrichment was developed. Kientz and Barnes [14] and Kientz et al. [15] reported an increase in rainbow trout (Oncorhynchus mykiss) growth using suspended aluminum rods and suspended strings of plastic spheres. Subsequent studies used a variety of vertically-suspended structures with a variety of salmonid species, including Chinook salmon (Oncorhynchus tshawytscha) [16]; brown trout (Salmo trutta) [17], Atlantic salmon (Salmo salar) [18], and rainbow trout [19] [20] [21] [22], showed similar results.

Although there have been numerous studies examining vertically-suspended environmental enrichment during the hatchery rearing of salmonids in circular tanks, these studies have primarily used juvenile or larger fish. No studies have examined the use of such enrichment beginning with initial feeding. Thus, the objective of this study was to evaluate the use of vertically-suspended environmental enrichment during the initial feeding and rearing of Chinook salmon.

\section{Methods}

This experiment was conducted at McNenny State Fish Hatchery, Spearfish, South Dakota, USA, using degassed and aerated well water at a constant temperature of $11^{\circ} \mathrm{C}$ (total hardness as $\mathrm{CaCO}_{3}, 360 \mathrm{mg} \cdot \mathrm{L}^{-1}$; alkalinity as $\mathrm{CaCO}_{3}, 210$ $\mathrm{mg} \cdot \mathrm{L}^{-1} ; \mathrm{pH}, 7.6$; total dissolved solids, $\left.390 \mathrm{mg} \cdot \mathrm{L}^{-1}\right)$. Approximately 10,000 (4.54 $\mathrm{kg} \cdot \operatorname{tank}^{-1}$ ) juvenile fall Chinook salmon (initial mean \pm SE; weight $0.38 \pm 0.01 \mathrm{~g}$, total length $37.88 \pm 0.38 \mathrm{~mm} ; n=30$ ) were placed into $10,2,000$-L circular tanks (1.8-m in diameter, 0.8-m deep, 0.6-m operating depth) on January 3, 2019. These fish had been feed trained for seven days prior to the start of the experiment. The study lasted 32 days, ending on February 5, 2019.

Two treatments $(n=5)$ were used. Corrugated plastic covered the top of all tanks, with only a small area open for feed delivery, as described by Walker et al. [23]. Control tanks had no structure present, while the other tanks had a vertically-suspended array of four aluminum angles. The aluminum angles (each side $2.5-\mathrm{cm}$ wide $\times 57.15-\mathrm{cm}$ long) were suspended through the corrugated plastic covers as described by Krebs et al. [19]. The angles were arranged so that the angled portion faced into the direction of water flow and did not inhibit the hydraulic self-cleaning of circular tanks [19].

The salmon were fed BioVita Starter (Bio-Oregon, Longview, Washington, USA) every 15 -min during daylight hours using automatic feeders. Feeding rates were determined by the hatchery constant method [24], with an expected feed conversion ratio of 1.1 and a projected growth rate of $0.08 \mathrm{~cm} \cdot \mathrm{d}^{-1}$, which was a rate slightly above satiation. 
At the end of the experiment, tanks of fish were weighed to the nearest $0.1 \mathrm{~kg}$ to obtain final tank weight. In addition, at the end of the study ten fish per tank were individually weighed to the nearest $0.01 \mathrm{~g}$ and measured (total length) to the nearest $0.1 \mathrm{~mm}$. Gain, percent gain, feed conversion ratio (FCR), specific growth rate (SGR), and condition factor (K) were calculated using the following formulas:

$$
\begin{gathered}
\text { Gain }=\text { end weight }- \text { start weight } \\
\text { Gain }(\%)=100 * \frac{\text { gain }}{\text { start weight }} \\
\text { Feed Conversion Ratio }(\mathrm{FCR})=\frac{\text { food fed }}{\text { gain }} \\
\text { Specific Growth Rate }(\mathrm{SGR})=100 * \frac{\ln (\text { end weight })-\ln (\text { start weight })}{\text { number of days }} \\
\text { Condition Factor }(\mathrm{K})=10^{5} * \frac{\text { fish weight }_{\text {fish length }}^{3}}{}
\end{gathered}
$$

Data were analyzed using the SPSS (24.0) statistical program (IBM, Armonk, New York, USA), with significance predetermined at $P<0.05$. T-tests were used to compare the variables from the vertically-suspended treatment group and the control group.

\section{Results}

Final tank weight, gain, percent gain, and feed conversion ratio were all significantly improved in the vertically-suspended environmentally enriched tanks compared to control tanks, with a nearly $25 \%$ improvement in feed conversion ratio (Table 1). Individual salmon in tanks with environmental enrichment were significantly longer and weighed significantly more than salmon from tanks without enrichment (Table 2). Specific growth rate was also significantly improved with the use of enrichment. Salmon were on average $1.5 \mathrm{~mm}$ longer and $0.1 \mathrm{~g}$ heavier in enriched tanks compared to un-enriched control tanks.

Table 1. Mean $( \pm$ SE) total tank weight, gain, percent gain, and feed conversion ratio (FCR) for landlocked fall Chinook salmon reared with (enriched) or without (control) vertically-suspended environmental enrichment. Means in a row with different letters are significantly different $(n=5, P<0.05)$.

\begin{tabular}{cccc}
\hline & Control & Enriched & $P$ \\
\hline Tank weight $(\mathrm{kg})$ & $15.2 \pm 0.7 \mathrm{z}$ & $17.5 \pm 0.3 \mathrm{y}$ & 0.02 \\
Gain (kg) & $10.6 \pm 0.7 \mathrm{z}$ & $13.0 \pm 0.3 \mathrm{y}$ & 0.02 \\
Gain (\%) & $234 \pm 16 \mathrm{z}$ & $286 \pm 6 \mathrm{y}$ & 0.02 \\
FCR $^{*}$ & $1.78 \pm 0.14 \mathrm{z}$ & $1.43 \pm 0.03 \mathrm{y}$ & 0.04 \\
\hline
\end{tabular}

* Feed Conversion Ratio $($ FCR $)=$ food fed/gain. 
Table 2. Mean ( \pm SE) final individual fish length (total), weight, specific growth rate (SGR), and condition factor (K) for landlocked fall Chinook salmon with (enriched) or without (control) vertically-suspended environmental enrichment. Means in a row with different letters are significantly different $(n=5, P<0.05)$.

\begin{tabular}{cccc}
\hline & Control & Enriched & $P$ \\
\hline Length $(\mathrm{mm})$ & $56.0 \pm 0.5 \mathrm{z}$ & $57.4 \pm 0.2 \mathrm{y}$ & 0.04 \\
Weight $(\mathrm{g})$ & $1.45 \pm 0.04 \mathrm{z}$ & $1.56 \pm 0.01 \mathrm{y}$ & 0.04 \\
$\mathrm{SGR}^{1}$ & $4.3 \pm 0.1 \mathrm{z}$ & $4.6 \pm 0.0 \mathrm{y}$ & 0.04 \\
$\mathrm{~K}^{2}$ & $0.83 \pm 0.02$ & $0.82 \pm 0.01$ & 0.70 \\
\hline
\end{tabular}

1. Specific growth rate $(\mathrm{SGR})=100 \times[(\ln ($ end weight $)-\ln ($ start weight $))$-number of days $], 2$. Condition factor $(\mathrm{K})=10^{5} \times\left[\right.$ weight $/\left(\right.$ length $\left.\left.{ }^{3}\right)\right]$.

\section{Discussion}

The results of this study clearly indicate that vertically-suspended environmental enrichment is beneficial during the initial rearing of Chinook salmon. These results are consistent with those observed using larger juvenile Chinook salmon by Rosburg et al. [16]. They are also consistent with the numerous other studies showing the positive impacts of vertically-suspended structures during hatchery rearing on the growth of other salmonid species during hatchery rearing in circular tanks [14] [15] [17]-[22] [25].

It is unknown how vertically-suspended enrichment is improving growth in hatchery-reared fish. Kientz et al. [15] hypothesized the benefits from vertically-suspended environmental enrichment were due to the creation of lower water velocity microhabitats that allowed the fish to decrease energy expenditures when not feeding [26]. The alterations in circular tank flow dynamics from vertically-suspended structure reported by Moine et al. [27] and Muggli et al. [28] support this hypothesis. The improved feed conversion ratios observed in this study provide further evidence of bioenergetic improvements with vertically-suspended enrichment. Because the salmon in the barren tanks were subjected to continual velocities, in comparison to the salmon in the enriched tanks containing locations with lower velocities, the fish in the unenriched tanks may have experienced exercise fatigue due to higher feed conversion ratios [25]. Other investigations not using suspended structures have also reported changes in overall water velocities can influence trout growth [29] [30] [31] [32].

As in previous studies utilizing vertically-suspended environmental enrichment, no negative effect on the self-cleaning nature of circular tanks was observed [19] [21] [22]. As long as adequate incoming water flows are maintained, no extra maintenance or cleaning is needed with the small array of angles as used in this study.

\section{Conclusion}

In conclusion, this study expands the window of expected benefits from vertically-suspended environmental enrichment to include the period of initial feed- 
ing, at least with landlocked fall Chinook salmon. These results are likely not specific to the unique form of vertically-suspended enrichment used, given the variety of other suspended structures shown to provide similar benefits in larger sized salmonids. However, the impacts of introducing vertically-suspended environmental enrichment during initial rearing on long-term hatchery rearing performance or post-stocking survival for those fish to be released into the natural waters are unknown. Further research should examine the use of vertically-suspended structures throughout the entire hatchery residence time of Chinook salmon.

\section{Acknowledgements}

We thank Misty Jones and Lynn Slama for their assistance with this project.

\section{Conflicts of Interest}

The authors declare no conflicts of interest regarding the publication of this paper.

\section{References}

[1] Bosakowski, T. and Wagner, E.J. (1995) Experimental Use of Cobble Substrates in Concrete Raceways for Improving Fin Condition of Cutthroat (Oncorhynchus clarkii) and Rainbow Trout (Oncorhynchus mykiss). Aquaculture, 130, 9-16. https://doi.org/10.1016/0044-8486(94)00223-B

[2] Berejikian, B.A., Tezak, E.J., Flagg, T.A., LaRae, A.L., Kummerow, E. and Mahnken, C.V.W. (2000) Social Dominance, Growth, and Habitat Use of Age-0 Steelhead Oncorhynchus mykiss Grown in Enriched and Conventional Hatchery Rearing Environments. Canadian Journal of Fisheries and Aquatic Sciences, 57, 628-636. https://doi.org/10.1139/f99-288

[3] Berejikian, B.A. and Tezak, E.P. (2005) Rearing in Enriched Hatchery Tanks Improves Dorsal Fin Quality of Juvenile Steelhead. North American Journal of Aquaculture, 67, 289-293. https://doi.org/10.1577/A05-002.1

[4] Salvanes, A.G.V., Moberg, O., Ebbesson, L.O.E., Nilsen, T.O., Jensen, K.H. and Braithwaite, V.A. (2013) Environmental Enrichment Promotes Neural Plasticity and Cognitive Ability in Fish. Proceedings of the Royal Society B, 280, Article ID: 20131331. https://doi.org/10.1098/rspb.2013.1331

[5] Roberts, L.J., Taylor, J., Gough, P.J., Forman, D.W. and Garcia de Leaniz, C. (2014) Silver Spoons in the Rough: Can Environmental Enrichment Improve Survival of Hatchery Atlantic Salmon Salmo salar in the Wild? Journal of Fish Biology, 85, 1972-1991. https://doi.org/10.1111/jfb.12544

[6] Bergendahl, I.A., Miller, S., Depasquale, C., Giralico, L. and Braithwaite, V.A. (2016) Becoming a Better Swimmer: Structural Complexity Enhances Agility in a Captive-Reared Fish. Journal of Fish Biology, 90, 1112-1117. https://doi.org/10.1111/jfb.13232

[7] Cogliati, K.M., Herron, C.L., Noakes, D.L.G. and Schreck, C.B. (2019) Reduced Stress Response in Juvenile Chinook Salmon Reared with Structure. Aquaculture, 504, 96-101. https://doi.org/10.1016/j.aquaculture.2019.01.056

[8] Tvinnereim, K. and Skybakmoen, S. (1989) Water Exchange and Self-Cleaning in 
Fish Rearing Tanks. In: De Pauw, N., Jaspers, E., Ackefors, H. and Wilkens, N., Eds., Aquaculture: A Biotechnology in Progress, European Aquaculture Society, Bredena, 1041-1047.

[9] Baynes, S.M. and Howell, B.R. (1993) Observations on the Growth, Survival and Disease Resistance of Juvenile Common Sole, Solea solea (L.), Fed Mytilus edulis L. Aquaculture and Fisheries Management, 24, 95-100. https://doi.org/10.1111/j.1365-2109.1993.tb00831.x

[10] Timmons, M.B., Summerfelt, S.T. and Vinci, B.J. (1998) Review of Circular Tank Technology and Management. Aquatic Engineering, 18, 51-69. https://doi.org/10.1016/S0144-8609(98)00023-5

[11] Tuckey, L.M. and Smith, T.I. (2001) Effects of Photoperiod and Substrate on Larval Development and Substrate Preference of Juvenile Southern Flounder, Paralichthys lethostigma. Journal of Applied Aquaculture, 11, 1-20. https://doi.org/10.1300/J028v11n01_02

[12] Lekang, O.-I. (2013) Aquaculture Engineering. 2nd Edition, Wiley-Blackwell, Chichester. https://doi.org/10.1002/9781118496077

[13] Krebs, J., Crank, K.M., Krebs, E. and Barnes, M.E. (2017) Use of Bottom Structure and Tank Cover During Rainbow Trout Rearing in Circular Tanks. Journal of Fisheries and Livestock Production, 5, 3. https://doi.org/10.4172/2332-2608.1000247

[14] Kientz, J. and Barnes, M.E. (2016) Structural Complexity Improves the Rearing Performance of Rainbow Trout in Circular Tanks. North American Journal of Aquaculture, 78, 203-207. https://doi.org/10.1080/15222055.2016.1159629

[15] Kientz, J., Crank, K.M. and Barnes, M.E. (2018) Enrichment of Circular Tanks with Vertically Suspended Strings of Colored Balls Improves Rainbow Trout Rearing Performance. North American Journal of Aquaculture, 80, 162-167. https://doi.org/10.1002/naaq.10017

[16] Rosburg, A.J., Fletcher, B.L., Barnes, M.E., Treft, C.E. and Bursell, B.R. (2019) Vertically-suspended Environmental Enrichment Structures Improve the Growth of Juvenile Landlocked Fall Chinook Salmon. International Journal of Innovative Studies in Aquatic Biology and Fisheries, 5, 17-24.

https://doi.org/10.20431/2454-7670.0501004

[17] White, S.C., Krebs, E., Huysman, N., Voorhees, J.M. and Barnes, M.E. (2019) Use of Suspended Plastic Conduit Arrays during Brown Trout and Rainbow Trout Rearing in Circular Tanks. North American Journal of Aquaculture, 81, 101-106. https://doi.org/10.1002/naaq.10076

[18] Jones, M.D., Krebs, E., Huysman, N., Voorhees, J.M. and Barnes, M.E. (2019) Rearing Performance of Atlantic Salmon Grown in Circular Tanks with Vertically-Suspended Environmental Enrichment. Open Journal of Animal Sciences, 9, 249-257. https://doi.org/10.4236/ojas.2019.92021

[19] Krebs, E., Huysman, N., Voorhees, J.M. and Barnes, M.E. (2018) Suspended Arrays Improve Rainbow Trout Growth during Hatchery Rearing in Circular Tanks. International Journal of Aquaculture and Fishery Sciences, 4, 3.

[20] Crank, K.M., Kientz, J.L. and Barnes, M.E. (2019) An Evaluation of Vertically-Suspended Environmental Enrichment Structures during Rainbow Trout Oncorhynchus mykiss Rearing. North American Journal of Aquaculture, 81, 94-100. https://doi.org/10.1002/naaq.10064

[21] Huysman, N., Krebs, E., Voorhees, J.M. and Barnes, M.E. (2019) Use of a Large Vertically Suspended Array in Circular Tanks during Juvenile Rainbow Trout Rearing. International Journal of Marine Biology and Research, 4, 1-5. 
[22] Huysman, N., Krebs, E., Voorhees, J.M. and Barnes, M.E. (2019) Use of Two Vertically-Suspended Environmental Enrichment Arrays during Rainbow Trout Rearing in Circular Tanks. International Journal of Innovative Studies in Aquatic Biology and Fisheries, 5, 25-30. https://doi.org/10.20431/2454-7670.0501005

[23] Walker, L.M., Parker, T.M. and Barnes, M.E. (2016) Full and Partial Overhead Tank Cover Improves Rainbow Trout Rearing Performance. North American Journal of Aquaculture, 78, 20-24. https://doi.org/10.1080/15222055.2015.1090504

[24] Buterbaugh, G.L. and Willoughby, H. (1967) A Feeding Guide for Brook, Brown, and Rainbow Trout. The Progressive Fish-Culturist, 29, 210-215. https://doi.org/10.1577/1548-8640(1967)29[210:AFGFBB]2.0.CO;2

[25] Voorhees, J.M., Huysman, N., Krebs, E. and Barnes, M.E. (2020) Influence of Water Velocity and Vertically-Suspended Structures on Rainbow Trout Rearing Performance. Open Journal of Animal Sciences, 10, 152-161.

https://doi.org/10.4236/ojas.2020.101008

[26] Fausch, K.D. (1984) Profitable Stream Positions for Salmonids: Relating Specific Growth Rate to Net Energy Gain. Canadian Journal of Zoology, 62, 441-445. https://doi.org/10.1139/z84-067

[27] Moine, J., Barnes, M.E., Kientz, J. and Simpson, G. (2016) Flow Patterns in Circular Rearing Tanks Containing Vertical Structure. Journal of Fisheries \& Livestock Production, 4, 4 .

[28] Muggli, A.M., Barnes, J.M. and Barnes, M.E. (2019) Vertically-Suspended Environmental Enrichment Alters the Velocity Profiles of Circular Fish Rearing Tanks. World Journal of Engineering and Technology, 7, 208-226. https://doi.org/10.4236/wjet.2019.71014

[29] Leon, K.A. (1986) Effect of Exercise on Feed Consumption, Growth, Food Conversion, and Stamina of Brook Trout. The Progressive Fish-Culturist, 48, 43-46. https://doi.org/10.1577/1548-8640(1986)48<43:EOEOFC>2.0.CO;2

[30] Kiessling, A., Higgs, D., Dosanjh, B. and Eales, J. (1994) Influence of Sustained Exercise at Two Ration Levels on Growth and Thyroid Function of All-Female Chinook Salmon Oncorhynchus tshawytscha in Seawater. Canadian Journal of Fisheries and Aquatic Sciences, 51, 1975-1984. https://doi.org/10.1139/f94-200

[31] Parker, T.M. and Barnes, M.E. (2014) Rearing Velocity Impacts on Landlocked Fall Chinook Salmon (Oncorhynchus tshawytscha) Growth, Condition, and Survival. Open Journal of Animal Sciences, 4, 244-252. https://doi.org/10.4236/ojas.2014.45031

[32] Parker, T.M. and Barnes, M.E. (2015) Effects of Different Water Velocities on the Hatchery Rearing Performance and Recovery from Transportation of Rainbow Trout Fed Two Different Rations. Transactions of the American Fisheries Society, 144, 882-890. https://doi.org/10.1080/00028487.2015.1047533 